\title{
SPOTLIGHT
}

\section{Health risks, present and future, from global climate change}

Tony McMichael and colleagues outline the risks climate change presents to health directly and indirectly, now and in the future

\author{
Tony McMichael professor of population health, Australia Fellow (National Health and Medical \\ Research Council) ${ }^{1}$, Hugh Montgomery professor of intensive care medicine, director ${ }^{2}$, Anthony \\ Costello professor of international child health, director ${ }^{3}$
}

${ }^{1}$ College of Medicine, Biology and Environment, Australian National University, Canberra, Australia; ${ }^{2}$ UCL Institute for Human Health and Performance, University College London; ${ }^{3} \mathrm{UCL}$ Institute for Global Health, University College London, London WC1N 1EH, UK

There is now no serious scientific debate: human actions are changing the world's climate, and are set to do so at an increasing rate in coming decades. ${ }^{12}$ Urgent action is now required to reduce emissions of carbon dioxide (the dominant long acting greenhouse gas), if global temperature rises are not to exceed $2^{\circ} \mathrm{C}$ - the International Energy Authority warns that "the door to $2^{\circ} \mathrm{C}$ is closing." ${ }^{, 3}$ Indeed, emissions must be hugely curtailed within just two decades, and then zero net emissions achieved by later this century, assisted by increased biosequestration of carbon dioxide from the atmosphere. ${ }^{4}$ However, emissions continue to rise, having increased by $49 \%$ since 1990 and by an accelerated annual rate of $5.9 \%$ in $2010 .^{5}$ As warming proceeds, the frequency and intensity of extreme weather events such as heatwaves, cyclones, floods, storm surges, heavy precipitation, and droughts are forecast to increase substantially. ${ }^{6}$ Many such changes are already becoming apparent worldwide. ${ }^{7} \Downarrow$

The meteorological (and resultant economic) impacts of climate change have been a major focus of public discussion, but associated threats to human health and survival have received much less attention. This may reflect, in part, a limited appreciation of the fundamental dependence of human population health on the natural environment's so called life support systems. People may also have a false sense of security engendered by the seeming invincibility of modern urban environments to inclement weather. But while industrialised urban societies may be complacent, many poor and vulnerable populations are already experiencing the health impacts of human induced climate change, whether through under-nutrition, diarrhoeal disease, extreme weather events, or sea level rise. However, as the tempo of extreme weather events increases, ${ }^{7}$ such impacts will be felt worldwide as the environmental and social foundations of population health—food and water supplies, natural constraints on infectious diseases, natural barriers against environmental disasters, and the stability and cohesion of societies - are disrupted and weakened.

\section{Risks to human health}

Climate change may bring health benefits to some, at least in the early stages of the process. ${ }^{8}$ Milder winters (albeit set against a rise in short term weather variability) may reduce deaths from influenza or cardiovascular disease in some temperate countries, while mosquito populations may recede in areas that become more arid. Improved coverage and use of bed nets, management of stagnant water and mosquito breeding sites, and greater availability of effective drugs may also (at a price) offset population risks from malaria vector expansion. ${ }^{9}$

The overall balance of health impacts of climate change, however, is anticipated to be substantially, and increasingly, negative. ${ }^{810} 11$ These negative effects are mediated not only through progressive changes in average climatic conditions, as temperatures rise and precipitation patterns change, ${ }^{8}$ but also through changes in regional weather patterns or their stability. Unpredictable weather (sudden cold, hot, wet, or dry spells) and extreme weather events (such as heatwaves, floods, and droughts) will become more common. These climatic changes affect human health through mechanisms that may be direct and indirect, immediate or delayed. ${ }^{10} 11$

Four categories of risk to human health can be described. 


\section{Immediate and direct risks}

Immediate and direct risks include the primary health impacts of heatwaves, extreme weather events, and altered air quality (especially increased concentrations of ground level ozone).

The frequency of extreme heat episodes will increase as average temperatures rise, and heatwaves and extreme weather events are also expected to become more frequent as climatic conditions become more variable. Ascribing any one particular extreme weather event to climate change is difficult, but scientific confidence has grown that we are already seeing such attributable impacts. ${ }^{12} 1314$ For example, it is estimated that climate change has already approximately doubled the probability that a heatwave as severe as the European heatwave in August 2003 will occur again. ${ }^{15}$ In November 2011 the Intergovernmental Panel on Climate Change (IPCC) special report on managing the risks of extreme events and disasters suggested that with a scenario of continuing high emissions it is likely that the frequency of heatwaves will increase in most regions. Heavy precipitation will occur more often, and the wind speed of tropical cyclones will increase and their number will likely remain constant or decrease. ${ }^{6}$

Recent experience of extremes of summer heat in Europe, Asia, and North America has underscored the great threat to health when physiological thresholds are passed. Once the human body's capacity to cope with increased thermal stress is exceeded, risks of homeostatic failure, disease exacerbation, and death begin to rise rapidly. This is especially the case in older people, those with underlying cardiovascular or chronic respiratory disease, and those who are poor, uneducated, or isolated (and therefore less likely to have access to, or take, preventive action). ${ }^{10}{ }^{16}$ Such effects are exacerbated by changes in air quality: ground level ozone levels rise with temperature, threatening human health. ${ }^{17}$ The greater absolute burden of adverse health impact from heatwaves will be in the general community, but workers in various heat exposed workplaces, both outdoors and indoors (if unventilated), are particularly vulnerable. $^{18}$

Societies will be hard pressed to prepare for and cope with extreme weather events, especially when these occur on a large scale. The flooding in Pakistan in July 2010 left $160000 \mathrm{~km}^{2}$ (or 62000 square miles, a fifth of the country's land mass) under water. 2010 also saw the hottest summer in Russia for 130 years, leading to forest and grassland fires burning a similar area, contributing to many deaths, and damaging grain crops. ${ }^{19}$

\section{Indirect risks}

Indirect risks arise from changes and disruptions to ecological and biophysical systems, affecting food yields, the production of aeroallergens (spores and pollens), bacterial growth rates, the range and activity of disease vectors (such as mosquitoes), and water flows and quality.

Rising temperatures reduce the solubility of gases (such as oxygen) in water: oxygen concentration at saturation falls $10 \%$ with a $3^{\circ} \mathrm{C}$ increase. Such effects may reduce fish stock density. Ocean fishery harvests are also affected by the adverse impacts of acidification (caused by increased uptake of carbon dioxide from the atmosphere) on the vitality of the marine food web base. $^{20}$

Crop and livestock yields are more sensitive to changes in climatic conditions than previously thought. Yields are impaired by relatively small changes in growing season temperatures. ${ }^{21}$ Rising temperatures affect rice production. ${ }^{22}$ Indeed, between 1980 and 2008, gains in crop yields due to factors such as technological advances may have been significantly offset by negative impacts of rising temperatures in many cropping regions of the world, often in association with changes in seasonal rainfall. Rice production in India, for example, peaked a decade ago, and the gains from the green revolution in South Asia are now over. ${ }^{23}$ Such negative impacts seem likely to progress to regions beyond South Asia, including southern Europe, the American Midwest, and southern Australia, ${ }^{8}$ with parts of Africa particularly vulnerable in the near future. ${ }^{24} 25$

Much attention has been paid to climate influence on food yields in relation to export earnings, livelihoods, and community incomes, but the ultimate manifestation of reduced yields is health impairment: hunger, under-nutrition, child stunting, susceptibility to infectious diseases, impaired adult health and strength, and premature death. In addition, climate induced falls in crop yield have potentially disastrous effects for the poor in terms of spiralling food prices. In 2011 the food price index of the Food and Agriculture Organization of the United Nations (FAO) matched its earlier peak in 2008, and has contributed to social unrest in the Middle East and elsewhere. Food prices are likely to stay high and volatile during the next few years because of factors including rising demand, and a likely increased frequency of extreme weather events. ${ }^{26}$

Changes in climatic conditions will affect many climate sensitive infectious diseases, via influences on pathogen maturation and multiplication, on vector organism density and behaviour (such as the mosquito), on the ecology and density of reservoir (intermediate) host species, and on aspects of human behaviour that amplify risks of infection (such as crowding and displacement). Thus, cases of campylobacteriosis, and infection with Salmonella Typhimurium and Salmonella Enteritidis rise with temperature. Such risks may be offset in countries with sufficient resources, but this may not be the case elsewhere. ${ }^{27}$

Changes in the distribution and life cycle of vector organisms will also occur, as will those of their transmitted pathogens. Changes in Lyme disease, malaria, schistosomiasis,

trypanosomiasis, onchocerciasis, and leishmaniasis are to be expected, as well as in dengue fever and infections by other arboviruses. ${ }^{28} 29$ The geographical distribution and timing of such changes are difficult to predict. For example, a short term increase in temperature and rainfall associated with the 1997-98 El Niño caused Plasmodium falciparum malaria epidemics in Kenya ${ }^{30}$ but reduced malaria transmission in Tanzania. ${ }^{31}$ Malarial zones have apparently extended to higher altitude in western Kenyan highlands ${ }^{32}{ }^{33}$; the schistosomiasis water snail survival zone has extended north in eastern China ${ }^{34}$; tick borne encephalitis zones have expanded northwards in Sweden; and the ixodid tick, which transmits Lyme disease, has spread northward in eastern Canada. ${ }^{11}{ }^{35}$ Taken together, these observations suggest that such impacts of climate change may already be taking place.

Surface runoff and solid material transportation (for instance, of organic materials) result from heavy rainfall, which is likely to rise in frequency in temperate countries as climate change progresses. Increased water contamination (both particulate and microbial, including from sewerage effluent) is thus likely. ${ }^{36}$ Gains in temperature and changes in rainfall and humidity may extend and intensify exposure to allergenic pollen and spores from plants such as ragweed. ${ }^{37} 38$

\section{Deferred and diffuse risks}

Deferred and diffuse risks to health include those associated with rural to urban displacement, ${ }^{39}$ and the mental health consequences of droughts in failing rural communities. A recent review from Australia suggests that, following a severe weather 
event, as many as one in five people will suffer debilitating effects of extreme stress, emotional injury, and despair. ${ }^{40}$ The emotional and psychological toll can linger for months or even years, affecting community wellbeing and the capacity for people to work. Children in particular are vulnerable to pre-disaster anxiety and post-trauma illness. The failure of adults to act on climate change may lead to long term insecurity and anxiety in young people, ${ }^{41}$ including chronic neurohormonal changes that affect long term disease processes.

\section{Risks associated with conflicts and environmental refugee flows}

That weather and climate can affect the risk of conflict is evident from history. ${ }^{42}$ Disease, starvation, drought, loss of habitat, loss of natural resources, and economic impacts are powerful drivers. Local wars in Africa in recent decades have peaked during very hot and dry years, in association with reduced food yields. ${ }^{43}$ Further evidence comes from study of the El Niño-Southern Oscillation (ENSO), which affects weather in many regions including Africa, Asia, and the Americas. In the warmer (El Niño) phase, land temperatures may rise and rainfall decline, bringing droughts that last several years. A study of 175 countries and 234 conflicts during 1950-2004 estimated that in the large subset of countries known to be affected by El Niño events, the chance of civil war breaking out doubled during such warmer spells. The study's authors calculated that El Niño may have played a role in over a fifth of civil conflicts since $1950 .{ }^{44}$ Such climatic drivers as these can also lead to migration, often to areas where resources are already strained, and the risk of conflict greater still.

Climate change thus acts as a force multiplier, amplifying the negative health impacts of other environmental stressors (such as land degradation, soil nitrification, depletion of freshwater stocks, ocean acidification, and biodiversity loss). Populations with high pre-existing rates of climate sensitive diseases and conditions, such as child diarrhoea, malaria, under-nutrition, asthma, atherogenic cardiovascular disease, and extreme heat exposures in workplace settings, could suffer large absolute increments in adverse health impact with relatively small changes in climate..$^{45}$ Indeed, conservative extrapolation of estimates made for the year 2000 suggested that climate change is now causing some 200000 premature deaths each year (from under-nutrition, diarrhoeal disease, malaria, and flooding), with over $90 \%$ of these occurring in low income countries (especially sub-Saharan Africa and South Asia), and $85 \%$ in children under 5 years of age. ${ }^{46}$

\section{The potential health co-benefits of taking mitigation action}

Many more localised health co-benefits should flow from national and local actions to reduce the atmospheric concentrations of greenhouse gases, in addition to the long term protection of health at global level. ${ }^{47}$ Local and regional air quality, for example, will improve from the reduction of fossil fuel combustion in the generation of power, thus lowering risks of respiratory and cardiovascular disease. An increase in the use of mass transit, cycling, and walking, as alternatives to more energy intensive private vehicles, will increase physical activity, reduce obesity, and stimulate social contacts. In high income countries, where the average daily intake of red meat is typically greater than nutritional requirements, a decrease in production and consumption of meat (especially from ruminant animals, including cattle, sheep, and goats) would confer health gains via reductions of cardiovascular and some cancer risks.
A further and fundamentally important set of health co-benefits would result from promoting reproductive rights for women, especially in low income countries. Improving access to family planning and health services for mothers and children will increase personal control over fertility and yield reductions in both maternal and child mortality, two of the key determinants in reducing the rate of growth in world population size-a basic determinant of total human impact on the global climate system.

\section{Adaptation and mitigation}

Climate change poses a grave threat to human health and survival and urgent and substantial efforts to limit greenhouse gas emissions (that is, mitigation) are essential. Meanwhile, public health action is needed to manage those risks already with us, or that will result from the locked in, but as yet latent, warming from past emissions (estimated at $\geq 0.7^{\circ} \mathrm{C}$ ). These adaptation strategies will range from near term ameliorative actions (such as early warning systems for impending weather extremes, enhanced infectious disease surveillance, and reinforced sea walls against storm surges) through to long term transformative actions, such as remodelling urban settlements to render them less vulnerable to climate change, demographic transition, and new modes of farming and strains of cultivars better able to cope with climate change.

The health sector should play a central role: to communicate the health risks of global heating, to collaborate with other (sometimes unfamiliar) partners, and to promote, lead and evaluate a range of adaptive strategies. ${ }^{48}$ In doing so, particular attention must be paid to protecting the health and safety of the most vulnerable sectors of populations. Globally, effective and equitably shared adaptive responses will require increased financial contributions by high income countries to low income countries, and a freer flow of information and technologies between countries.

\section{What we need to do}

Human induced climate change is a reality, and one which threatens our biosphere and the global economy. It also poses a grave threat to our health and survival, and an even greater risk to our children and grandchildren. Urgent action at national and international level is required to minimise emissions of greenhouse gases, while adaptive mechanisms are put in place to deal with those health consequences that are already unavoidable.

TMcM heads a large epidemiological research programme on climate change and health, has made substantive contributions to health risk assessment by the Intergovernmental Panel on Climate Change (IPCC) over two decades, and is a science adviser to the Australian Government's Climate Commission. HM has been engaged in climate and health issues for over a decade. He was a co-author of the UCL/Lancet Commission report on climate and health, co-founded the UCL MSc course in climate and health, and has authored a number of reviews and articles on the topic. He was a founding member of the UK Climate and Health Council. AC has a longstanding research interest on reproductive and population health issues in resource poor countries including India, Nepal, Bangladesh, and Malawi. He chaired the UCL/Lancet Commission on Managing the Health Effects of Climate Change. This article arose from a meeting of health and military professionals in London, in November 2011, which HM helped organise, and was drafted jointly by the authors, each of whom has reviewed and summarised the related scientific literature a number of times over the past decade, including an updated literature review for this article. 
Competing interests: All authors have completed the ICMJE uniform disclosure form at www.icmje.org/coi_disclosure.pdf (available on request from the corresponding author) and declare: no support from any organisation for the submitted work; no financial relationships with any organisations that might have an interest in the submitted work in the previous three years; and no other relationships or activities that could appear to have influenced the submitted work.

Provenance and peer review: Commissioned; not externally peer reviewed.

Rahmstorf S. A new view on sea level rise. Nature Reports Climate Change 2010:4:44-5.

2 Meinshausen M, Meinshausen N, Hare W, Raper SCB, Frieler K, Knutti R, et al. Greenhouse-gas emission targets for limiting global warming to $2^{\circ} \mathrm{C}$. Nature 2009;458:1158-62

3 International Energy Agency. World Energy Outlook November 2011. www. worldenergyoutlook.org/docs/weo2011/executive_summary.pdf.

4 Friedlingstein $\mathrm{P}$, Solomon S, Plattner G-K, Knutti R, Ciais P, Raupach MR. Long-term climate implications of twenty-first century options for carbon dioxide emission mitigation. Nature Climate Change 2011;1:457-61.

5 Peters GP, Marland G, Le Quéré C, Boden T, Canadell JG, Raupach MR. Rapid growth in $\mathrm{CO}_{2}$ emissions after the 2008-2009 global financial crisis. Nature Climate Change 2012;2:2-4.

6 Intergovernmental Panel on Climate Change (IPCC). Managing the risks of extreme events and disasters to advance climate change adaptation (SREX). Special report on risks of extreme events. IPCC, 2011. www.ipcc-wg2.gov/SREX.

7 Schiermeier Q. Climate and weather: extreme measures. Nature 2011;477:148-9.

8 Intergovernmental Panel on Climate Change (IPCC). Climate change 2007: Impacts, adaptation and vulnerability. Contribution of Working Group II to the Fourth Assessment Report of the Intergovernmental Panel on Climate Change. Parry ML, Canziani OF, Palutikof JP, van der Linden PJ, Hanson CE, eds. Cambridge University Press, 2007.

9 Snow RW, Marsh K. Malaria in Africa: progress and prospects in the decade since the Abuja Declaration. Lancet 2010;367:137-9.

10 Costello A, Abbas M, Allen A, Ball S, Bell S, Bellamy R, et al. Managing the health effects of climate change: Lancet and University College London Institute for Global Health Commission. Lancet 2009;373:1693-733.

11 McMichael AJ, Lindgren E. Climate change: present and future risks to health, and necessary responses. J Intern Med 2011;270:401-13.

12 Pall P, Aina T, Stone DA, Stott PA, Nozawa T, Hilberts AG, et al. Anthropogenic greenhouse gas contribution to flood risk in England and Wales in autumn 2000. Nature 2011;470:382-5.

13 Min SK, Zhang X, Zwiers FW, Hegerl GC. Human contribution to more-intense precipitation extremes. Nature 2011;470:378-81

14 Dole R, Hoerling M, Perlwitz J, Eisheid J, Pegion P, Zhang T, et al. Was there a basis for anticipating the 2010 Russian heat wave? Geophys Res Lett 2011;38:L06702.

15 Stott PA, Stone DA, Allen MR. Human contribution to the European heatwave of 2003. Nature 2004:432:610-4

16 Hajat S, Armstrong B, Baccini M, Biggeri A, Bisanti L, Russo A, et al. Impact of high temperatures on mortality: is there an added heat wave effect? Epidemiology 2006;17:632-8.

17 The Royal Society. Ground-level ozone in the 21st century: future trends, impacts and policy implications. The Royal Society, 2008. http://royalsociety.org/policy/publications/ 2008/ground-level-ozone.

18 Kjellstrom T. Climate change, direct heat exposure, health and well-being in low and middle income countries. Global Health Action 2009;2.

19 Gilbert N. Russia counts environmental cost of wildfires. Nature News 12 August 2010.

20 Sumaila UR, Cheung WWL, Lam VWY, Pauly D, Herrick S. Climate change impacts on the biophysics and economics of world fisheries. Nature Climate Change 2011;1:449-56.

21 Lobell DB, Field CB. Global scale climate-crop yield relationships and the impacts of recent warming. Environ Res Let 2007;2:014002.

22 Peng S, Huang J, Sheehy JE, Laza RC, Visperas RM, Zhong X, et al. Rice yields decline with higher night temperature from global warming. Proc Natl Acad Sci U S A 2004;101:9971-5.

23 Lobell DB, Schlenker W, Costa-Roberts J. Climate trends and global crop production since 1980. Science 2011;333:616-20.
24 Parry M, Rosenzweig C, Livermore M. Climate change, global food supply and risk of hunger. Philos Trans R Soc Lond B Biol Sci 2005;360:2125-38.

25 Lloyd SJ, Kovats RS, Chalabi Z. Climate change, crop yields, and undernutrition: development of a model to quantify the impact of climate scenarios on child undernutrition. Environ Health Perspect 2011;119:1817-23.

26 Terazono E. UN says food prices to remain high. Financial Times 10 October 2011.

27 Lake IR, Gillespie IA, Bentham G, Nichols GL, Lane C, Adak GK, et al. A re-evaluation of the impact of temperature and climate change on foodborne illness. Epidemiol Infect 2009:137:1538-47.

28 Sutherst RW. Global change and human vulnerability to vector-borne diseases. Clin Microbiol Rev 2004;17:136-73.

29 Gage KL, Burkot TR, Eisen RJ, Hayes EB. Climate and vector-borne diseases. Am J Prev Med 2008;35:436-50.

30 World Health Organization. El Niño and its health impacts. Wkly Epidemiol Rec 1998;73:148-52.

31 Lindsay SW, Bodker R, Malima R, Msangeni HA, Kisinza W. Effect of 1997-98 El Niño on highland malaria in Tanzania. Lancet 2000;355:989-90.

32 Pascual M, Ahumada JA, Chaves LF, Rodó X, Bouma M. Malaria resurgence in the East African highlands: temperature trends revisited. Proc Nat Acad Sci U S A 2006;103:5829-34.

33 Omumbo JA, Lyon B, Waweru SM, Connor SJ, Thomson MC. Raised temperatures over the Kericho tea estates: revisiting the climate in the East African highlands malaria debate. Malar J 2011;10:12

34 Zhou XN, Yang GJ, Yang K, Wang XH, Hong QB, Sun LP, et al. Potential impact of climate change on schistosomiasis transmission in China. Am J Trop Med Hyg 2008;78:188-94.

35 Ogden NH, Maarouf A, Barker IK, Bigras-Poulin M, Lindsay LR, Morshed MG, et al. Climate change and the potential for range expansion of the Lyme disease vector Ixodes scapularis in Canada. Int J Parasitol 2006;36:63-70.

36 Delpla I, Jung AV, Baures E, Clement M, Thomas O. Impacts of climate change on surface water quality in relation to drinking water production. Environ Int 2009;35:1225-33.

37 Ziska L, Knowlton K, Rogers C, Dalan D, Tierney N, Elder MA, et al. Recent warming by latitude associated with increased length of ragweed pollen season in central North America. Proc Natl Acad Sci U S A 2011;108:4248-51.

38 Beggs PJ, Bambrick HJ. Is the global rise of asthma an early impact of anthropogenic climate change? Environ Health Perspect 2005;113:915-9.

39 McMichael AJ, Friel S, Nyong T, Corvalan C. Global environmental change and health: impacts, inequalities, and the health sector. BMJ 2008;336:191-4.

40 The Climate Institute. A climate of suffering: the real cost of living with inaction on climate change. The Climate Institute, 2011. www.climateinstitute.org.au/our-publications/reports/ 874-aclimateofsuffering.

41 Strazdins L, Friel S, McMichael AJ, Woldenberg Butler S, Hanna EG. Climate change and children's health: likely futures, new inequities? Int $J$ Pub Health 2011:2:493-500.

42 Zhang DD, Lee HF, Wang C, Li B, Pei Q, Zhang J, et al. The causality analysis of climate change and large-scale human crisis. Proc Natl Acad Sci U S A 2011;108:17296-301.

43 Burke MB, Miguel E, Satyanath S, Dykema JA, Lobell DB. Warming increases the risk of civil war in Africa. Proc Natl Acad Sci U S A 2009;106:20670-4.

44 Hsiang SM, Meng KC, Cane MA. Civil conflicts are associated with the global climate. Nature 2011;476:438-41.

45 Rockström J, Steffen W, Noone K, Persson A, Chapin FS 3rd, Lambin EF, et al. A safe operating space for humanity Nature 2009;461:472-5.

46 McMichael AJ, Campbell-Lendrum D, Kovats S, Edwards S, Wilkinson P. Wilson T, et al. Global climate change. In: Ezzati M, Lopez AD, Rodgers A, Murray CJL, eds. Comparative quantification of health risks: global and regional burden of disease due to selected major risk factors. World Health Organization; 2004:1543-1650. www.who.int/publications/cra/ chapters/volume2/1543-1650.pdf.

47 Haines A, McMichael AJ, Smith KR, Roberts I, Woodcock J, Markandya A, et al. Public health benefits of strategies to reduce greenhouse-gas emissions: overview and implications for policy makers. Lancet 2009;374:2104-14.

48 Pencheon D. Health services and climate change: what can be done? J Health Serv Res Policy 2009;14:2-4.

Accepted: 20 January 2012

Cite this as: BMJ 2012:344:e1359

(c) BMJ Publishing Group Ltd 2012 
Figure

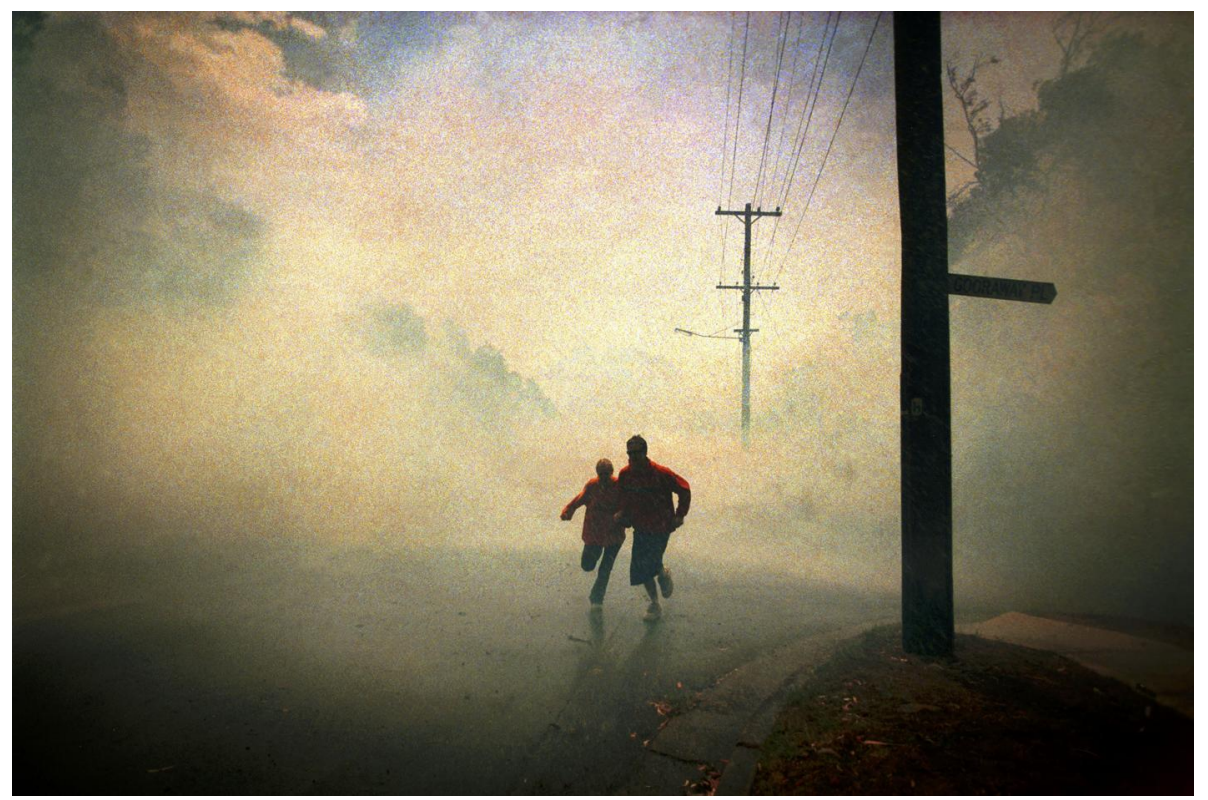

